\title{
IN SITU INVESTIGATION OF WORKING BATTERY ELECTRODES USING SYNCHROTRON X-RAY DIFFRACTION
}

N.M.JISRAWI" $I^{*}$ T.R.THURSTON ${ }^{*}, X . Q$. YANG $^{+}, S \cdot$ MUKERJEE $^{+}, J^{+}$, MCBREEN $^{+}$, M.L.DAROUX ${ }^{++}, \mathrm{X} . \mathrm{K} . \mathrm{XING}^{++}$

* Dept. of Physics, Birzeit University, P.O.Box 14, West Bank.

**Dept. of Physics, Brookhaven National Laboratory, Upton, NY 11973, USA.

+Dept. of Applied Science, Brookhaven National Laboratory, Upton, NY 11973, USA.

++Gould Electronics, Eastlake, OH 44095, USA.

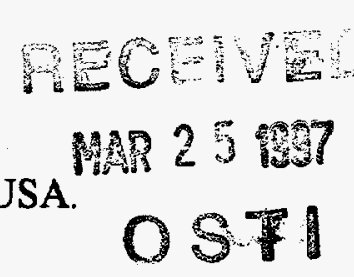

\section{ABSTRACT}

The results of an in situ investigation of the structural changes that occur during the operation of working battery electrodes using synchrotron radiation are presented. Two types of electrodes were investigated: an $\mathrm{AB}_{2}$-type Laves phase alloy anode with the composition $\mathrm{Zr}_{\mathrm{x}} \mathrm{Ti}_{1-\mathrm{x}} \mathrm{M}_{2}$ and a proprietary cell based on $\mathrm{Li}_{\mathrm{x}} \mathrm{Mn}_{2} \mathrm{O}_{4}$ spinel compound cathode made by Gould electronics. For the Laves phase alloy compositions with $\mathrm{x}=0.25$ and 0.5 and $\mathrm{M}=\mathrm{V}_{0.5} \mathrm{~N}_{1.1} \mathrm{Mn}_{0.2} \mathrm{Fe}_{0.2}$ were examined. Cells made from two different batches of $\mathrm{Li}_{x} \mathrm{Mn}_{2} \mathrm{O}_{4}$ material were investigated. The relationships between battery performance and structural changes will be discussed. In the later case, we also discuss the role of overdischarging on the $\mathrm{Li}_{\mathbf{x}} \mathrm{Mn}_{2} \mathrm{O}_{4}$ structure and on battery operation.

\section{INTRODUCTION}

Considerable research efforts have devoted to the development of stable, low cost, reproducible battery materials.[1,2] Two of the more important families of materials are hydrogen-absorbing alloys and spinel-type $L i$ insertion electrodes. The importance of these two families of batteries cannot be over-emphasized. Metal-hydride batteries have been widely studied, but systematic in situ studies of batteries in operation remain to be done.[3] In situ structural studies on operating battery electrodes can provide guidance in optimizing alloy compositions with desirable performance characteristics. However, it is difficult to investigate operating batteries because it is necessary for the probing radiation to penetrate not only the cell walls and electrolyte, but also through the electrode itself, if changes that occur in the bulk of the electrode are to be monitored.

$\mathrm{Li}$ insertion electrodes with the spinel structure have been studied extensively since Hunter [4] showed that the spinel can be a $\mathrm{Li}$ insertion compound. The so-called "rocking chair" batteries used as secondary(rechargeable) cells have generated much commercial interest because of their relative safety (no free $\mathrm{Li}$ is being used ). In these batteries, an intercalation compound other than $\mathrm{Li}$ is used for the anode and the battery voltage depends on the difference between the chemical potential of $\mathrm{Li}$ in the two electrodes. Ohzuku et. al. Did the first systematic in situ study in which some of the phases that occur during $\mathrm{Li}$ intercalation were identified. [5] However, $\mathrm{LiMn}_{2} \mathrm{O}_{4}$ exhibits many different structural properties depending on the initial processing conditions, and Ohzuku et al examined $\mathrm{LiMn}_{2} \mathrm{O}_{4}$ processed under only one set of conditions. In this investigation, we 
report on an in situ investigation in which hard $\mathrm{x}$-rays from a synchrotron source were used to probe the bulk of the operating electrode for $\mathrm{LiMn}_{2} \mathrm{O}_{4}$ processed differently from Ohzuku et al.

\section{EXPERIMENTAL DETAILS}

The experiments as described elsewhere[6], were was performed at beamline $X$ $27 \mathrm{~A}$ at the National Synchrotron Light Source. $X$-rays with energy $\sim 24.5 \mathrm{KeV}(\lambda$ $\sim 0.505 \mathrm{~A}$ ) were used. White light from the synchrotron was monochromatized using a bent $\mathrm{Si}(111)$ crystal of the type used by the medical group at the NSLS.[7] The samples, consisting of a specially made cell in the case of the nickel-hydride and a proprietary cell for the $\mathrm{Li}_{\mathbf{x}} \mathrm{Mn}_{2} \mathrm{O}_{4}$, were placed in a transmission geometry in a two circle goniometer. An $\mathrm{LiF}(200)$ crystal was used as an analyzer. The construction of the nickel-metal hydride cell has been described in detail in Ref. [6] and [8]. The thickness of the metal-nickel-hydride anode was $\sim 0.5 \mathrm{~nm}$ and both anode and carbon cathode were immersed in a 6 molar $\mathrm{KOH}$ solution. The $\mathrm{Li}_{\mathbf{X}} \mathrm{Mn}_{2} \mathrm{O}_{4}$ cells were manufactured by Gould electronics for the purposes of this experiment as $2 \mathrm{~cm} \times 5 \mathrm{~cm} \times 0.5 \mathrm{~mm}$ cells, but were otherwise similar in construction to their commercial cells. The cells contained a carbon anode and nonaquaeous electrolyte. They were factory sealed in a plastic casing with a fixed amount of $\mathrm{Li}$ available for intercalation into the cathode so that $\mathrm{x}$ was always less than 1 . Different charging cycles were applied to each set of electrodes while $\mathrm{x}$-ray data was continuously taken. A custommade cycler was used to control the charging state of the $\mathrm{Li}_{\mathbf{X}} \mathrm{Mn}_{2} \mathrm{O}_{4}$ - battery while in situ cycling of the $\mathrm{AB}_{2}$ cell was done using standard cyclic voltammetry apparatus.

\section{RESULTS}

\section{The Laves Phase $\mathrm{AB}_{2}$ Material:}

Two $\mathrm{AB}_{2}$ compositions were studied in this investigation. First, a cell with an anode made of $\mathrm{Zr} 0.5 \mathrm{Ti} 0.5 \mathrm{~V} 0.5 \mathrm{Ni} 1.1 \mathrm{Mn} 0.2 \mathrm{Fe} 0.2$ was prepared and activated by cycling more than ten times. The cell was then charged to a voltage $\sim 1.4 \mathrm{~V}$ and moved to the synchrotron beam line where it was allowed to discharge through an external resistor. The structural changes that occur during the discharge process were observed directly via $\mathrm{x}$ ray diffraction. This demonstration experiment was done to show the utility of the method. The changes that occur during the discharge process are discussed in some detail in Ref. 6 . In Fig. 1 we show results obtained on another alloy with a more complex structure. The alloy used here is $\mathrm{Zr} 0.25 \mathrm{Ti} 0.75 \mathrm{~V}_{0.5} \mathrm{Ni}_{1.1} \mathrm{Mn} 0.2 \mathrm{Fe} 0.2$ which is a mixture of two phases in its unhydrided state. The figure shows a set of $x$-ray $\theta-2 \theta$ scans taken after the electrode with the above composition was activated then charged to a voltage of $1.4 \mathrm{~V}$. The cell was then taken to the beam line and discharged while $\mathrm{x}$-ray scans were taken. The data in figure 1 show that peaks with intensities up to $20,000 / \mathrm{sec}$ can be obtained readily with this technique, even though the $\mathrm{x}$-rays had to penetrate through electrolyte, binding materials, all casings, and the electrodes themselves. The first scan shown corresponds to a cell 


\section{DISCLAIMER}

This report was prepared as an account of work sponsored by an agency of the United States Government. Neither the United States Government nor any agency thereof, nor any of their employees, make any warranty, express or implied, or assumes any legal liability or responsibility for the accuracy, completeness, or usefulness of any information, apparatus, product, or process disclosed, or represents that its use would not infringe privately owned rights. Reference herein to any specific commercial product, process, or service by trade name, trademark, manufacturer, or otherwise does not necessarily constitute or imply its endorsement, recommendation, or favoring by the United States Government or any agency thereof. The views and opinions of authors expressed herein do not necessarily state or reflect those of the United States Government or any agency thereof. 


\section{DISCLAIMIER}

Portions of this document may be illegible in electronic image products. Images are produced from the best available original document. 
voltage of $1.27 \mathrm{~V}$ which is considered an intermediate state. The other scans also show the complicated intermediate behavior of this alloy.

$$
\mathrm{Zr}_{0.25} \mathrm{Ti}_{0.75} \mathrm{~V}_{0.5} \mathrm{Ni}_{1.1} \mathrm{Mn}_{0.2} \mathrm{Fe}_{0.2}
$$

Figure 1: $X$-ray $\theta-2 \theta$ scans for the $\mathrm{AB}_{2}$ material with the composition $\mathrm{Zr}_{0.2} \mathrm{Ti}_{0.75} \mathrm{M}_{2}$ ( see text). The unhydrided material is a mixture of a b.c.c. phase ( $13 \%$ ) and a $\mathrm{C} 14$ Laves phase $(87 \%)$. In addition binder material peaks are also visible (feature G). The figure shows the complicated behavior of the material during the intermediate states of partial hydrogen charging. Such states cannot be studied easily using ex-situ methods. In the figure we have also indexed peaks belonging to the C14 Laves phase for the unhydrided material. There are: $F:(110), E:(103), D:(200), C:(112)$, $B:(201)$, and $A:(004)$.

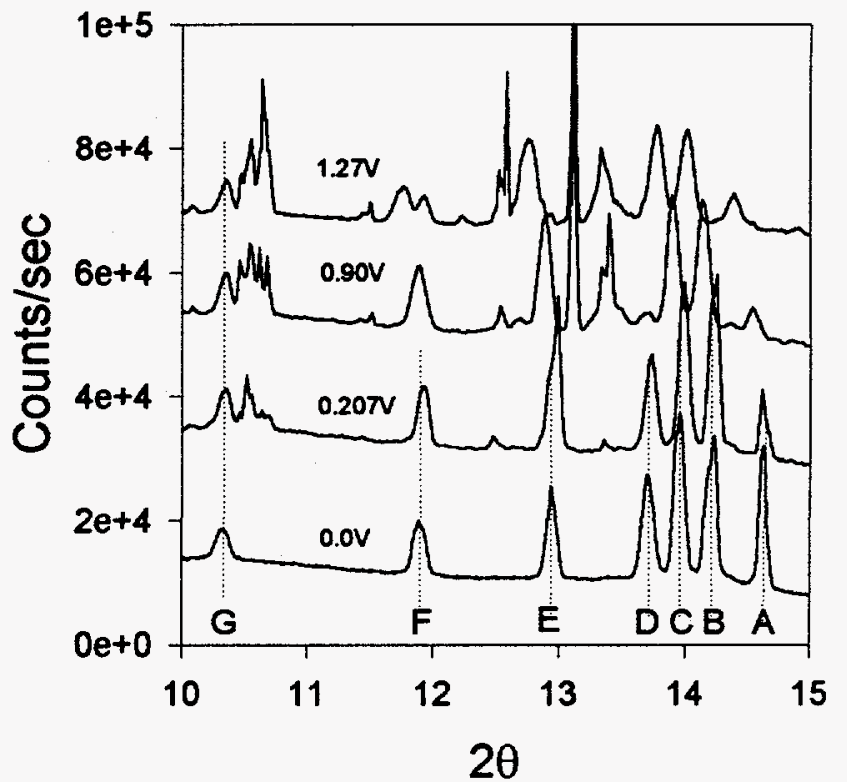

\section{$\underline{\mathrm{Li}}_{\underline{x}} \mathrm{Mn}_{2} \underline{\mathrm{O}}_{4}$ Cathodes:}

Fresh cells of this type were obtained from Gould electronics. The x-ray diffraction experiments were performed while the cells were connected to a cycler. Fig. 2 is a plot of the voltage versus capacity for one such cell where the following experiments were done:

1) An initial charging cycle was done where the cell was charged from 0 to $4.2 \mathrm{~V}$. The charging current used was $200 \mu \mathrm{A}$. The voltage-capacity $(\mathrm{V}-\mathrm{C})$ curve for this initial charge can be divided into 4 distinct regions, each associated with special structural changes as explained in detail in Ref. 9. We discuss here briefly the main features of this cycle. Region $I$ is characterized by irreversible changes where a multiphase $\mathrm{LiMn}_{2} \mathrm{O}_{4}$ material converts into single phase material at a constant voltage of $\sim 1.5 \mathrm{~V}$. As discussed in Ref. 9, the existence of this plateau seems to be dependent on the preparation conditions for the $\mathrm{Li}_{X} \mathrm{Mn}_{2} \mathrm{O}_{4}$ material. This result is of practical importance because it could be used as a method for discerning batches of $\mathrm{LiMn}_{2} \mathrm{O}_{4}$ with favorable properties. Another plateau at $3.3 \mathrm{~V}$ ( region II) is where $\mathrm{Li}$ is intercalated into the carbon anode while the $\mathrm{Li}_{\mathrm{x}} \mathrm{Mn}_{2} \mathrm{O}_{4}$ lattice contracts as $\mathrm{Li}$ is removed. In this region the $\mathrm{Li}_{\mathrm{x}} \mathrm{Mn}_{2} \mathrm{O}_{4}$ is single phase. In region III, two cubic phases coexist with distinct lattice constants, while single phase behavior is recovered in region IV which extends up to $4.3 \mathrm{~V}$. 


\section{$\mathrm{Li}_{x} \mathrm{Mn}_{2} \mathrm{O}_{4}$}

Figure 2: $\mathrm{Li}_{\mathrm{x}} \mathrm{Mn}_{2} \mathrm{O}_{4}$ cell potential plotted against cell capacity for the initial charging cycle. Four distinct regions are seen in the plot as detailed in the text. The figure also shows data for the first discharge cycle. Note that the $3.3 \mathrm{~V}$ plateau loses much of its capacity during the first cycle.

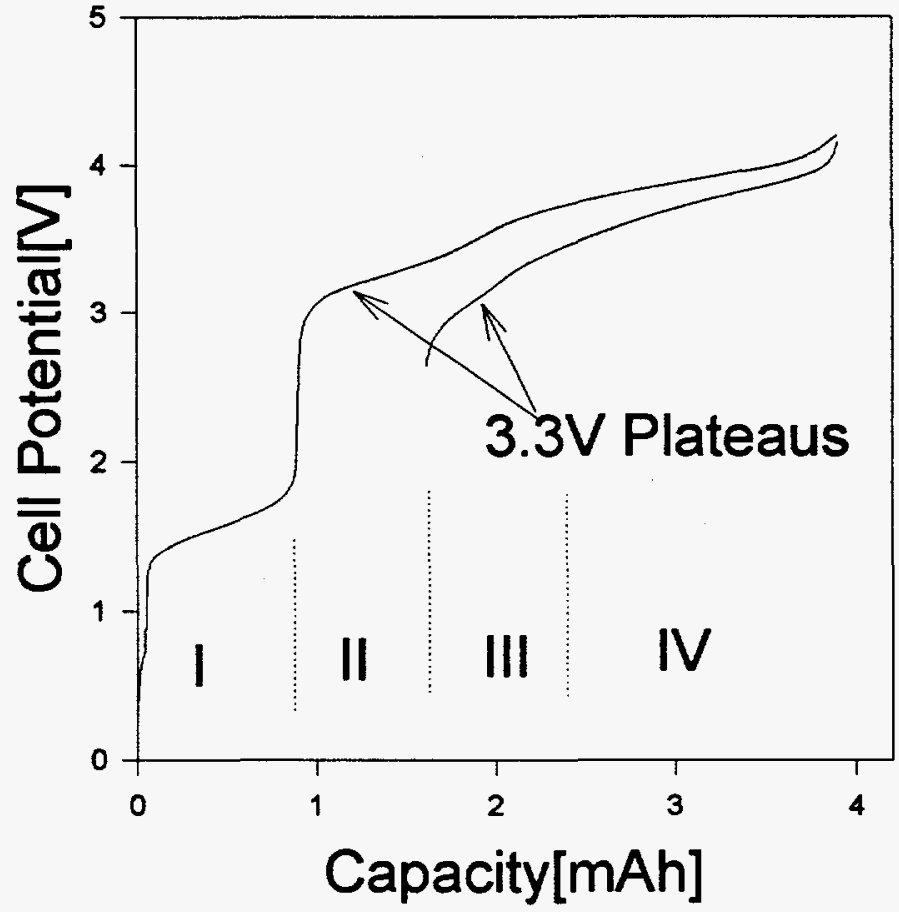

2) The cell was then discharged slowly to a voltage higher than $2.2 \mathrm{~V}$, held and then recycled between $2.2 \mathrm{~V}$ and $4.3 \mathrm{~V}$. This relatively fast procedure was designed to study changes that occur during the activation process. While the two-phase coexistence region is retained over the appropriate voltage range, that plateau voltages changed during the discharge process. The capacity of the battery in the region of the $3.3 \mathrm{~V}$ plateau was extremely reduced.

3) The cell is finally over-discharged while $x$-ray scans are done to study the structural changes during this final phase. As will be shown below the $\mathrm{Li}_{\mathrm{x}} \mathrm{Mn}_{2} \mathrm{O}_{4}$ lattice is permanently deformed and will not charge again as before.

Figure 3 compares $x$-ray $\theta-2 \theta$ scans for the cell when it was fresh, overdischarged, and fully charged to a voltage of $4.2 \mathrm{~V}$. The peaks for the over-discharged cell are broad and diffuse compared to those of the fresh cell. Other $\mathrm{X}$-ray data shows that when charged again, the peaks will not sharpen as in the initial cycle. Instead, damage to the cell seems to be permanent. 


\section{$\mathrm{Li}_{x} \mathrm{Mn}_{2} \mathrm{O}_{4}$-Carbon Cell, $\lambda=.505 \mathrm{~A}$}

Figure 3: $\theta-2 \theta$ scans for the $\mathrm{Li}_{x} \mathrm{Mn}_{2} \mathrm{O}_{4}$ electrode. Three scans are shown which compare between the cell when it was fresh, fully charged, and overdischarged. The $\mathrm{x}$-ray peaks for the overdischarged cell are permanently deformed.

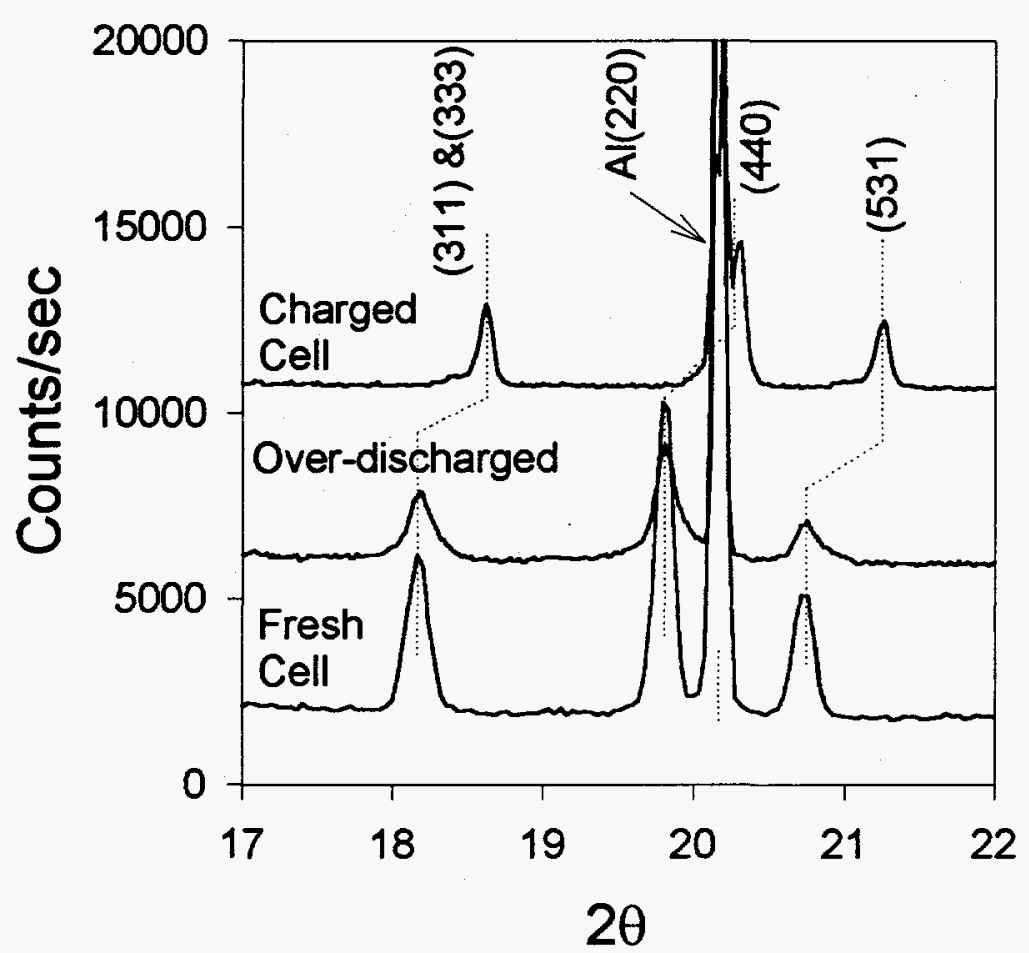

\section{RESULTS AND DISCUSSION}

The structural and microstructural changes that occur during the operation of battery cells are very important because they have a direct affect on their performance. We have discussed in other publications that synchrotron hard $\mathrm{x}$-rays provide a powerful technique by which these changes can be monitored, and that differences in battery performance due to sample preparation can readily be correlated with these structural changes. $[6,8]$ Data shown here provide two more examples of the power of this method.

Firstly, the data on $\mathrm{AB}_{2}$ compounds shows that the technique can be applied to many types of systems. In this case the example is the mixed phase material $\mathrm{Zr}_{0.25} \mathrm{Ti}_{0.75} \mathrm{M}_{2}$. In its unhydrided state this material is a mixture of a b.c.c. phase (13\%) and the cubic Laves phase $\mathrm{C} 14$ (87\%). In this preliminary experiment, the cell was charged to a voltage of $1.4 \mathrm{~V}$ and then disconnected from the charger and brought to the beamline in its charged state. Figure 1 shows $\theta-2 \theta$ scans for the unhydrided cell and three scans taken during the discharge process. All three scans illustrate the complex behavior during intermediate charging states of alloy. Peaks belonging to both phases and also to the binder material are visible in the scans. In this first experiment on this alloy, our goal was only to demonstrate the capabilities of the method in looking at such complex behavior. In future experiments, we plan to study this behavior in detail by doing the charging and discharging in situ and by tracing the various phases and their behavior as the cells are charged and discharged. 
Second, we have the data on the "rocking chair" $\mathrm{Li}_{x} \mathrm{Mn}_{2} \mathrm{O}_{4}$-carbon cell. The changes that occur in these cells during the first charging cycle were discussed in another publication. [9] There it was shown that irreversible changes occur during this cycle that were different depending on the batch of material used in each battery and its preparation conditions. These batteries can be operated at two different plateau voltages. At 3.9V a "lever rule" situation occurs as conversion occurs between two coexisting cubic phase with different lattice constants. The other plateau is at $4.1 \mathrm{~V}$ when $\mathrm{Li}$ insertion or extraction is reflected as an expansion (contraction) of the $\mathrm{Li}_{\mathrm{x}} \mathrm{Mn}_{2} \mathrm{O}_{4}$ lattice. It is known that these batteries should be operated between these voltages and never to be overdischarged below a nominal voltage of $2.0 \mathrm{~V}$. In this study we have deliberately overdischarged batteries below that voltage while observing changes to the crystal structure of the underlying $\mathrm{Li}_{x} \mathrm{Mn}_{2} \mathrm{O}_{4}$ lattice. It is shown in Fig. 3 that the spinel peaks are broadened and their intensity reduced, due to damage done to the lattice. Later attempts to charge the cell after over-discharging have failed showing that this damage is permanent. We believe that this experiment is of importance because it may help identify the reasons behind this damage. Further work is planned where the goal is to identify the critical voltages beyond which permanent damage occurs and hence to help battery manufacturers identify the proper operating limits for their batteries.

\section{ACKNOWLEDGMENTS}

This work was supported by the U.S. Department of Energy under contract No. DE-AC02-76CH00016.

\section{REFERENCES}

1. J.M. Tarascon, E. Wang, F. K. Shokoohi, W.R. McKinnon, and S. Colson, J. Electrochem. Soc. 138, 2859(1991); J. M. Tarascon and D. Guyomard, ibid., 2864(1991). 2. M. M. Thackery, A.de Kock, and W.I. David, Mat. Res. Bull., 28, 1041-1049(1993). 3. J. Huot, E. Akiba, T. Ogura, and Y. Ishido, J. Alloys and Compounds, 218, 101109(1995).

4. J.C. Hunter, J. Solid State Chem., 39, 142(1981).

5. T. Ohzuku, M. Kitagawa, and T. Hirai, , J. Electrochem. Soc. 137, 769(1990).

6. T.R. Thurston, N.M. Jisrawi, S. Mukerjee, X.Q. Yang, J. McBreen, M.L. Daraoux, and X.K. Xing, Appl. Phys. Lett., 69, 194(1996).

7. P. Suortti, W. Thomlinson, D. Chapman, N. Gmur, D.P.Siddons, and C. Schulze, Nucl. Instrum. Methods A, 336, 304(1993).

8. S. Mukerjee, J. McBreen, J.J. Reilly, J.R. Johnson, G. Adzik, K. Petrov, M.P.S. Kumar, W. Zhang, and S. Srinivasan, , J. Electrochem. Soc. 142, 2278(1995).

9. N. M. Jisrawi, X.Q. Yang, S. Mukerjee, T.R. Thurston, J. McBreen, M.L. Daraoux, and X.K. Xing, submitted to J. Electrochem. Soc. 